Original Research Paper

\title{
Effect of Drying Method on Physical-Chemical Characteristics and Amino Acid Content of Tropical Alfalfa (Medicago sativa L.) Hay for Poultry Feed
}

\author{
Bambang Suwignyo, Anita Mustika, Kustantinah, Lies Mira Yusiati and Bambang Suhartanto \\ Faculty of Animal Science, Universitas Gadjah Mada, Jl. Fauna 3, Bulaksumur, Yogyakarta 55281, Indonesia
}

\author{
Article history \\ Received: $12-02-2020$ \\ Revised: $18-04-2020$ \\ Accepted: 08-05-2020 \\ Corresponding Author: \\ Bambang Suwignyo \\ Faculty of Animal Science, \\ Universitas Gadjah Mada, Jl. \\ Fauna 3, Bulaksumur, \\ Yogyakarta 55281, Indonesia \\ Email: bsuwignyo@ugm.ac.id
}

\begin{abstract}
Alfalfa is an important source of inexpensive forage for poultry that has high nutritional and digestive value. Alfalfa can be dried to produce hay, although the drying method can affect the quality of the hay as forage. In this study we examined how drying methods affect the physical quality and chemical composition of hay produced from alfalfa (Medicago sativa L.). Harvested alfalfa plants were dried by direct sun exposure (P1), under a tarp in a greenhouse (P2), or in an oven at $55^{\circ} \mathrm{C}(\mathrm{P} 3)$. The physical and chemical characteristics of the hays were analyzed and differences among the three treatment groups were analyzed with ANOVA followed by Duncan's New Multiple Range Test (DMRT). Samples dried under direct sunlight (P1) had reduced crude fat content and increased crude fiber content compared to the other treatments. However, the physical and chemical characteristics of hay produced by all three treatments were within recommended ranges for quality forage. Furthermore, the heat associated with oven-drying did not affect the amino acid content of the resulting hay. Taken together, hay can be rapidly produced by oven-drying to produce an economical alternative source of protein that is comparable to that in corn, soybean and fish meals.
\end{abstract}

Keywords: Forage, Feed, Greenhouse, Medicago sativa L, Tropics

\section{Introduction}

The availability of adequate amounts of good quality feed is critical for successful animal husbandry at both small and large scales. Forage is an affordable feed source and legume forage in particular is a cheaper source of protein than most cereals. Alfalfa (Medicago sativa L.) is a type of Leguminosae that is highly nutritional and has a high protein content (Suwignyo et al., 2016; Taghizadeh, et al., 2008). Moreover, alfalfa can grow and produce fertile seeds in tropical regions such as Indonesia (Suwignyo et al., 2017).

Medicago sativa is a leguminous plant that has been grown for a variety of purposes such as medicinal uses, a suitable foliage and animal feed (Ehsanpour and Razavizadeh, 2005). Alfalfa is used across the world as an important source of inexpensive forage that has both high nutritional and digestive value. Based on these characteristics, alfalfa is often referred to as the "Queen of Forage Crops" (Small, 2011). Compared to other types of Leguminosae, alfalfa has distinct advantages including a comprehensive range of macro- and micronutrients, as well as vitamins and amino acids (Sajimin, 2011). Alfalfa also has high digestibility and dry and organic matter content.

The protein content of alfalfa dry matter can range from $18 \%$ to $25 \%$ (Orloff and Carlson, 1997). The chlorophyll content in alfalfa plants is four-fold higher than that for similar legume plants. Meanwhile, the digestibility as measured in vitro does not vary significantly among alfalfa varieties (Suwignyo et al., 2014). Alfalfa has potential as feedstuff, either for ruminants or non ruminants animal.

To facilitate long-term storage, alfalfa must be dried into hay having a moisture content $<15 \%$. Hay production can be achieved through natural and artificial drying. Natural drying can be done using sunlight, either directly or indirectly with aeration. Alfalfa can also be artificially dried using a drying apparatus, such as an oven heated to $55^{\circ} \mathrm{C}$ (Utomo, 2015). Hay quality is determined based on the nutritional content, color, lack of mold and uniformity 
of plants. Physical and chemical characteristics are also used to assess hay quality.

Drying can alter both the physical and chemical composition of alfalfa. As such, determination of the effects of drying methods on these characteristics is important in order to ensure production of quality alfalfa hay forage.

\section{Materials and Methods}

The study was conducted between June 2018 and November 2018. Planting was done in a field used for forage collection at the Faculty of Animal Science, Universitas Gadjah Mada (UGM). The land was prepared for two weeks in advance of planting. The plants were maintained for two months in the field before harvest and analytical studies of plant samples. Chemical composition analysis of dry weight, ash weight, crude fiber and crude fat was performed at the Animal Forage and Pasture Science Laboratory and crude protein analysis was carried out at the Biochemistry Laboratory, Faculty of Animal Science UGM.

Alfalfa plants (Medicago sativa L.) were harvested at 21 days at the tenth regrowth stage and weighed on a scale having a $10 \mathrm{~kg}$ capacity and a sensitivity of $0.1 \mathrm{~kg}$. The alfalfa was then dried using the indicated method (see below). Samples of uniform weight were prepared by weighing on an electric scale having a sensitivity of $0.0001 \mathrm{~g}$. Proximate analysis testing was carried out using chemicals for proximate analysis according to AOAC (2005).

Alfalfa plants were harvested 21 days after the previous cutting (early flowering period) at the base of the plant stem, about $5 \mathrm{~cm}$ above the ground.

Three treatments were used to produce hay: P1: Drying under direct sunlight; P2: Drying under a tarp in a greenhouse without direct sunlight exposure; and P3: Drying in an oven at $55^{\circ} \mathrm{C}$. After harvest, $50 \mathrm{~g}$ samples were prepared in 3 replications. Stable weights were obtained after 17, 21 and 7 days for P1, $\mathrm{P} 2$ and $\mathrm{P} 3$, respectively.

Physical quality of the hay was assessed by observing the hay color, the presence or absence of mold and drying time. Chemical quality was measured by chemical composition analysis. Hay samples were chopped and ground using a Wiley mill with $1 \mathrm{~mm}$ filter porosity before Dry Matter (DM), Organic Matter (OM), Crude Protein $(\mathrm{CP})$, Crude Fiber $(\mathrm{CF})$ and Ether Extract
(EE) content were measured (AOAC, 2005). Proximate analysis results were used to calculate the amount of Nitrogen Free Extract (NFE) and Total Digestible Nutrients (TDN) (Harris et al., 1972).

Data for temperature, color and time of hay production are presented descriptively and the data for the chemical composition of the hay were subjected to analysis of variance (One Way ANOVA) based on a completely randomized design. Differences among treatments were assessed with Duncan's New Multiple Range Test (DMRT) (Duncan, 1955). Data for the amino acid content of the different treatments are presented as the mass present in samples.

\section{Results and Discussion}

\section{Physical Characteristics of Hay}

The quality of hay from alfalfa (Medicago sativa L.) was assessed by physical and chemical analysis (Table 1). Color, odor, presence of mold and time to reach dryness were assessed for physical qualities. Chemical quality was determined by measuring content of nutrients (Rusdy, 2017).

The three treatments produced hay of different colors that were likely due to exposure to different temperatures. P3 retained a greener color than did P1 and P2 and none of the treatments had mold. These results indicate that oven-drying produced better quality hay, which is consistent with previous findings that good quality hay has a bright green color (Utomo, 2015) that is similar to the color of the plant prior to drying. Quality hays also lack dirt and mold (Utomo, 2015).

The time needed to produce hay varied among the treatments due to weather influences. This result aligns with the theory of Rusdy (2017) wherein factors that affect the duration of hay processing in the field included sunlight, relative humidity, groundwater content and wind speed. Here, the drying time of hay using an oven at $55^{\circ} \mathrm{C}(\mathrm{P} 3)$ tended to be shorter than that for $\mathrm{P} 1$ and $\mathrm{P} 2$.

\section{Chemical Composition of Hay}

Next, proximate analysis results for the different treatments were obtained from chemical tests to determine the nutrient content of raw feed material or feed, namely Dry Matter (DM), Organic Matter (OM), Crude Protein $(\mathrm{CP})$, Crude Fiber $(\mathrm{CF})$, Ether Extract (EE) and Nitrogen Free Extracts (NFE; Table 2).

Table 1: Physical characteristics of alfalfa hay (Medicago sativa L.)

\begin{tabular}{llll} 
& Treatment & & \\
Physical characteristic & P1 & P2 & P3 \\
\hline Color & Chocolate & Brownish-green & Green \\
Fungi present & None & None & None \\
Drying time (days) & 17 & 21 & 7 \\
\hline
\end{tabular}


The results of variance analysis showed that drying method significantly $(\mathrm{P}<0.05)$ affected the chemical composition (DM, CP, CF, Ether Extract (EE) and Nitrogen Free Extract (NFE)) of hay alfalfa (Medicago sativa L.), although values for Organic Matter (OM) were similar among the three drying treatments.

Using values for hay dried at $55^{\circ} \mathrm{C}(\mathrm{P} 3)$ as a baseline, differences among the three treatments were less than $10 \%$ for DM, OM and NFE, which were between $0.5 \%$ (OM in P1-P3) and 6.5\% (NFE in P1-P3). Utomo (2015) stated that after natural drying variations in DM (20$30 \%)$, CP (27 to 30\%) and TDN (25-28\%) can be observed. These variations can largely be attributed to weather wherein longer drying periods due to lack of sun diminish the chemical characteristics. Meanwhile, these factors are not affected during artificial drying when a constant temperature is maintained.

The nutritional value of the hay samples produced using the three treatments was still within a reasonable range. Utomo (2015) found that hay made from alfalfa harvested before flowering has a crude protein content of $21.10 \%$, ADF of $30.20 \%$ and digestibility of $63.30 \%$.
Results of Sajimin (2011) indicated that alfalfa had ranges for crude protein, ADF and NDF of 16.0\%-29.1\%, 16.2\%$25.4 \%$ and $40.45 \%-44.9 \%$ respectively. Alfalfa from the Ciawi region in Indonesia has a crude protein content of 24.6\% Sajimin (2011). Meanwhile, Wahyuni and Kamaliyah (2009) showed that alfalfa harvested at 80 days has a crude protein content of $19.54 \%$.

The nutritional value of crude fiber for P1, P2 and P3 was inversely proportional to that of TDN and NFE. This result is consistent with that of Sari et al. (2015), who showed that decreases in crude fiber content of feed material are associated with increased NFE content.

Alfalfa is also known to have superior nutritional value relative to other feeds and in particular has a desirable protein content. A study by Orloff and Carlson (1997) demonstrated that digestibility and protein content are two components that can be used to distinguish the quality of alfalfa. The protein content of dried alfalfa ranges between 18 and $25 \%$ and this content can be affected by heat. Thus, we measured the amino acid content of hay produced using heat treatment, P3 (Table 3).

Table 2: Proximate analysis of chemical composition of hay alfalfa

\begin{tabular}{|c|c|c|c|}
\hline \multirow[b]{2}{*}{ Chemical Composition (\%) } & \multicolumn{3}{|l|}{ Treatment } \\
\hline & $\mathrm{P} 1$ & $\mathrm{P} 2$ & P3 \\
\hline Dry matter $(\mathrm{DM})$ & $21.27 \pm 0.65^{\mathrm{ab}}$ & $20.93 \pm 0.14^{\mathrm{a}}$ & $21.70 \pm 0.11^{\mathrm{b}}$ \\
\hline Organic matter $(\mathrm{OM})$ & $89.44 \pm 1.93^{\mathrm{ns}}$ & $90.41 \pm 1.74^{\mathrm{ns}}$ & $89.86 \pm 0.73^{\mathrm{ns}}$ \\
\hline Ether extract & $2.88 \pm 0.40^{\mathrm{a}}$ & $5.43 \pm 0.52^{\mathrm{b}}$ & $6.47 \pm 0.52^{\mathrm{c}}$ \\
\hline Crude fiber & $30.07 \pm 2.22^{b}$ & $23.64 \pm 3.32^{\mathrm{a}}$ & $22.71 \pm 2.04^{\mathrm{a}}$ \\
\hline Crude protein & $18.31 \pm 2.54^{\mathrm{a}}$ & $22.80 \pm 2.26^{\mathrm{b}}$ & $19.87 \pm 1.44^{\mathrm{a}}$ \\
\hline NFE & $38.18 \pm 1.39^{\mathrm{a}}$ & $38.53 \pm 2.27^{\mathrm{ab}}$ & $40.82 \pm 2.52^{\mathrm{b}}$ \\
\hline $\mathrm{TDN}^{*}$ & $31.55 \pm 6.10^{\mathrm{a}}$ & $54.93 \pm 10.12^{\mathrm{b}}$ & $57.61 \pm 6.45^{\mathrm{b}}$ \\
\hline
\end{tabular}

Table 3: Amino acid contents of fresh alfalfa and hay (unit in $\%$ and $\mathrm{mg} / \mathrm{kg}$ )

\begin{tabular}{|c|c|c|c|c|}
\hline \multirow[b]{2}{*}{ Amino acid } & \multicolumn{2}{|l|}{$\%$} & \multicolumn{2}{|l|}{$\mathrm{mg} / \mathrm{kg}$} \\
\hline & Fresh & Hay & Fresh & Hay \\
\hline L-Arginine & 0.57 & 0.72 & $5,689.63$ & $7,162.13$ \\
\hline L-Histidine & 0.28 & 0.31 & $2,793.39$ & $3,055.50$ \\
\hline L-Lysine* & 0.58 & 0.54 & $5,799.48$ & $5,428.27$ \\
\hline L-Phenylalanine & 0.92 & 0.88 & $9,228.61$ & $8,822.42$ \\
\hline L-Isoleucine & 0.83 & 0.88 & $8,292.53$ & $8,776.48$ \\
\hline L-Leucine* & 1.21 & 1.13 & $12,050.00$ & $11,250.00$ \\
\hline L-Tyrosine & 0.37 & 0.27 & $3,708.51$ & $2,721.48$ \\
\hline L-Methionine ${ }^{*}$ & 0.10 & 0.07 & $1,002.12$ & 658.28 \\
\hline L-Valine & 1.01 & 1.03 & $10,109.50$ & $10,306.69$ \\
\hline L-Proline & 0.47 & 0.50 & $4,708.62$ & $5,016.90$ \\
\hline L-Glutamic acid & 1.57 & 1.64 & $15,650.00$ & $16,350.00$ \\
\hline L-Aspartic acid & 0.87 & 1.02 & $8,704.89$ & $10,157.37$ \\
\hline L-Cysteine* & 0.00 & 0.01 & 48.48 & 55.62 \\
\hline L-Threonine & 0.68 & 0.71 & $6,828.14$ & $7,121.49$ \\
\hline L-Serine & 0.52 & 0.61 & $5,210.79$ & $6,067.45$ \\
\hline L-Alanine & 0.88 & 0.80 & $8,762.68$ & $7,972.85$ \\
\hline L-Glycine & 0.77 & 0.75 & $7,671.19$ & $7,520.96$ \\
\hline
\end{tabular}

Results of amino acid analysis at Laboratoy of PPT UGM (2019)

*amino acid typically found in soybean, corn and fish meal 
The content of several amino acids decreased, while others increased follow heat processing. However, these differences were not significant (T-test). As such, the heat treatment did not substantially affect the protein content or amount of amino acids in the resulting hay.

Based on the measured amino acid content, these results indicate that alfalfa can be a suitable alternative for other feed materials that provide necessary amounts of several amino acids for poultry including corn meal (lysine and tryptophan), soybean meal (methionine, cysteine, lysine and tryptophan) and fish meal (methionine and lysine). Lysine requirements for poultry are reported to range from $0.45 \%$ to $0.85 \%$, whereas those for methionine are between $0.10 \%$ and $0.32 \%$ (Parkhurt and Mountney, 1988). Sitompul (2004) stated that lysine and methionine are limiting amino acids in feed and thus are critical considerations when formulating poultry feed mixtures. In 10 types of fish meals the lysine content was higher than the recommended amount at $2.71-3.90 \%$. The methionine content in fish meal is also higher $(0.99 \%$ $2.71 \%)$ as is that for soybean meal $(1.17-2.91 \%$ and $0.7 \%$ $2.51 \%$ for lysine and methionine, respectively). Suarnidan (2016) showed that the protein content in seed corn was between 8 and $11 \%$ and the lysine and tryptophan content was $0.05 \%$ and $0.225 \%$, respectively. All of these feeds have amino acid contents that are higher than the recommended amount for poultry and the alfalfa hay samples analyzed here would be thus predicted to meet the nutritional needs of poultry at a lower cost.

\section{Conclusion}

The method for drying alfalfa with oven-drying at $55^{\circ} \mathrm{C}$ produced acceptable and consistent DM, crude fat, crude protein, NFE and TDN contents compared to that obtained with drying in direct sunlight and indirect drying. The chemical composition of oven-dried hay did not differ substantially from that for the other methods and the amino acid content was preserved. The processing time, meanwhile, was substantially lower. Together these results indicate that oven-drying of alfalfa to produce hay yields a suitable forage and thus this method can be used to provide economically valuable alternatives to corn, soybean meal and fish meal.

\section{Acknowledgment}

The researchers wish to thank Galih Pawening, Heru Sasongko, Eprilia Aristia Rini and Dean Ali Agus for their support and assistance.

\section{Author's Contributions}

Bambang Suwignyo: Designed the research plan, organized the study, covered all budget for research, coordinated the data-analysis and contributed to the writing of the manuscript.
Anita Mustika: Participated in experiment in the field (data gathering) and processing research data.

Kustantinah: Advised during constructing research plan, data collection and writing manuscript.

Lies Mira Yusiati: Advised during writing manuscript, evaluated the final draft before submitted.

Bambang Suhartanto: Advised during data analyses and writing manuscript.

\section{Ethics}

This research does not content any ethical issues (did not harm to human, animal). The research was done with objectivity, integrity, carefulness, respect for intellectual property, responsible, and legality.

\section{References}

AOAC, 2005. Official Methods of Analysis Association of Official Analytical Chemists. 1st Edn., AOAC Washington DC., pp: 76

Ehsanpour, A.A. and R. Razavizadeh, 2005. Effect of UV-C on drought tolerance of alfalfa (Medicago sativa) callus. Am. J. Biochem. Biotechnol., 1: 107-110. DOI: 10.3844/ajbbsp.2005.107.110

Suwignyo, B., B. Putra, N. Umami, C. Wulandari and R. Utomo, 2016. Effect of phosphate fertilizer and arbuscular mycorrhizal fungi on the nutrient content, phosphate uptake and in vitro digestibility of alfalfa. Buletin Peternakan, 40: 203-210. DOI: 10.21059/buletinpeternak.v40i3.12401

Duncan, D.B., 1955. Multiple range and multiple F test. Biometrics, 11: 1-42. DOI: $10.2307 / 3001478$

Harris, L.E., L.C. Kearl and P.V. Fonnesbeck, 1972. Use of regression equation in predicting availability of energy and protein. J. Anim. Sci., 65: 658-664. DOI: $10.2527 /$ jas $1972.353658 x$

Orloff, S.B. and H.L. Carlson, 1997. Intermountain Alfalfa Management. 1st Edn., Agriculture and Natural Resources Publications, ISBN-10: 1879906244, pp: 138.

Parkhurt, C.R. and G.J. Mountney, 1988. Poultry Nutrition. In: Poultry Meat and Egg Production, Parkhurt, C.R. and G.J. Mountney (Eds.), Springer, Boston, pp: 110-125.

Rusdy, M., 2017. Pengawetan hijauan pakan. CV. Social Politic Genius (SIGn), Makassar.

Sajimin, 2011. Medicago sativa L (Alfalfa) sebagai tanaman pakan ternak harapan di indonesia. Wartazoa, 21: 91-98. DOI: $10.14334 /$ wartazoa.v21i2.985

Sari, M.L., A.I.M. Ali., S. Sandi and A. Yolanda, 2015. Kualitas serat kasar, lemak kasar, dan betn terhadap lama penyimpanan wafer rumput kumpai minyak dengan perekat karaginan. J. Peternakan Sriwijaya, 4: 35-40. DOI: 10.33230/JPS.4.2.2015.2805 
Small, E., 2011. Alfalfa and Relatives: Evolution and Classification of Medicago. 1st Edn., NRC Research Press, Otawa, Canada, ISBN-10: 1845937503, pp: 727.

Suwignyo, B., B. Suhartanto, C.T. Noviandi, N. Umami and N. Suseno et al., 2017. Generative plant characteristics alfalfa (Medicago sativa $\mathrm{L}$.) on different levels of dolomite and lighting duration. Proceeding of the 1st International Conference on Tropical Agriculture, (CTA' 17), Springer, Switzerland, pp: 353-361.

DOI: 10.1007/978-3-319-60363-6_34

Suwignyo, B., R. Subantoro and Y. Prapto, 2014. Nutrition values and digestibility of three varieties alfalfa (Medicago sativa $\mathrm{L}$ ) were inoculated with rhizobium assorted. Proceedings of the 16th AAAP Animal Science Congress, Nov. 10-14, Gadjah Mada University, Yogyakarta, Indonesia.
Sitompul, S., 2004. Analisis asam amino dalam tepung ikan dan bungkil kedelai. Buletin Teknik Pertanian, 9: 33-37.

Suarnidan, S.W., 2016. Struktur, komposisi dan nutrisi jagung. Balai Penelitian Tanaman dan Serealia. Balai Besar Penelitian dan Pengembangan Pasca Panen Pertanian Bogor

Taghizadeh, A., V. Palangi and A. Safamehr, 2008. Determining nutritive values of alfalfa cuts using in situ and gas production techniques. Am. J. Anim. Vet. Sci., 3: 85-90. DOI: 10.3844/ajavsp.2008.85.90

Utomo, R., 2015. Konservasi hijauan pakan dan peningkatan kualitas bahan pakan berserat tinggi. Gadjah Mada University, Yogyakarta.

Wahyuni, R.D. and S.N. Kamaliyah, 2009. Studi tentang pola produksi alfalfa tropis (Medicago sativa $\mathrm{L}$.). J. Ilmu-ilmu Peternakan, 19: 20-27. 